\title{
A Report on the Death of Mixed Infection of HEV and HBV
}

\author{
Yonggang $Q u^{1,2}$, Yujian Zheng1, Chuangfu Chen², Guangze Zhu3 ${ }^{3}$ Ningyi Jin³ \\ ${ }^{1}$ School of Public Health, Xinjiang Medical University, Urumqi, China \\ ${ }^{2}$ College of Animal Science and Technology, Shihezi University, Shihezi, China \\ ${ }^{3}$ Genetic Engineering Laboratory, Academy of Military Medical Sciences, Changchun, China \\ Email: zhyujian6@sina.cn
}

Received January 2015

\begin{abstract}
Mixed infection with hepatitis E virus (HEV) in patients with chronic hepatitis B virus (HBV) infection is frequent. HEV mixed infection often leads to activation of hepatic pathological changes and worsens the inflammatory activity. However, it is not known clearly how these two types of virus influence each other in human body. Intensive investigation has revealed that HEV mixed infection inhibits HBV replication. We have just encountered a relative rare case. The patient who was a HBV carrier and was infected by HEV. Before he was infected by the HEV, the measurement of his HBV DNA fixed quantity examination on fluorescence was $<10^{3}$ copies $/ \mathrm{ml}$; his routine biochemistry was normal; and his anti HEV-IgM and anti-HEV-IgG appeared to be negative reaction. After he was infected by HEV, his routine biochemistry increased, and the measurement of his HBV DNA fixed quantity examination on fluorescence was $8.51 \times 10^{5}$ copies $/ \mathrm{ml}$. It indicated that the replication of HBV was activated after the patient infected HEV. Finally, he was dead. This case revealed that HEV mixed infection may activate the replication of HBV, not inhibit HBV replication, and demonstrated the needs for further studies about the mechanism of the interaction of the two viruses.
\end{abstract}

\section{Keywords}

Hepatitis E Virus, Hepatitis B Virus, Mixed Infection

\section{Introduction}

Mixed infection with hepatitis E virus (HEV) occurred in patients with chronic hepatitis B virus (HBV) infection is frequent [1]-[18]. It often leads to activation of hepatic pathological changes and worsens the inflammatory activity [1] [2], causes severe liver decompensation, which is frequently complicated with hepatic encephalopathy and renal failure. Acute hepatitis $\mathrm{E}$ in these patients has a protracted course with high morbidity and mortality [3]. However, it is not known clearly how these two types of virus influence each other in human body. Intensive investigation has revealed that HEV mixed infection inhibits HBV replication [1] [4]-[6].

Whereas, we encountered a relatively rare case. The patient had a acute HEV infection, who has been a HBV carrier for 20 years. The replication of HBV was activated remarkably after the patient infected HEV. 


\section{Case Report}

The patient was 46 years old. 20 years ago, his HBsAg, HBeAb and HBcAb all appeared to be positive reaction without any relevant symptoms. He was diagnosed by the local physician as "hepatitis B" and was occasionally treated with the help of some liver-protecting medicine. He had no record of drinking, injury, operation, blood transfusion, or other infectious diseases, but had a 20-year-smoking history. Before he was infected by the HEV, the measurement of his HBV DNA fixed quantity examination on fluorescence was $<10^{3}$ copies $/ \mathrm{ml}$; his routine biochemistry was normal; and his anti HEV-IgM and anti-HEV-IgG appeared to be negative reaction.

On the 29th of December, the patient had the symptoms of sudden weakness, anorexia, fever and icterus. Physical examination on admission results are as following: body temperature $38.1^{\circ} \mathrm{C}$; pulse $72 /$ minute; blood pressure 120/80 mmHg; no abnormal evidence shown in neck artery and vein; soft abdomen; no pressed pain and no rebounding pain of the upper part of the side; touched appendix ensiformis to $3.0 \mathrm{~cm}$ with slippery surface, side parts and slight pressed pain; Murphy's sign appeared negative reaction; throbbing pain in liver area.

His laboratory tests on admission revealed: serum anti-HEV-IgM and anti-HEV-IgG were positive; alphafetoprotein (AFP) $5.0 \mathrm{ug} / \mathrm{L}$; total bilirubin (TBiL) $95.8 \mu \mathrm{mol} / \mathrm{L}$, alanine aminotransferase (ALT) $894 \mathrm{U} / \mathrm{L}$, aspartate aminotransferase (AST) $1300 \mathrm{U} / \mathrm{L}$, and gamma-glutamyl transpeptidase (GGT) $221 \mathrm{U} / \mathrm{L}$, all were increased; total protein (TP) $75.3 \mathrm{~g} / \mathrm{L}$, albumin (ALB) $40 \mathrm{~g} / \mathrm{L}$, all were decreased; cholinesterase (CHE ) 4653 U/L (Table 1).

He was diagnosed as acute HEV infection based on the symptom and the laboratory test results.

Immediately after he was hospitalized, his routine biochemistry increased (Table 1), and the measurement of his HBV DNA fixed quantity examination on fluorescence was $8.51 \times 10^{5}$ copies $/ \mathrm{ml}$. Blood clotting system test revealed: prothrombin time (PT), international normalized ratio(INR), activated partial thromboplastin time (APTT), thrombin time (TT), and fibrinogen (FIB) increased; prothrombin time ratio (PTR) decrease (Table 2).

It showed a large-area necrosis on the liver of the patient through transoesophageal echocardiography (Figure 1).

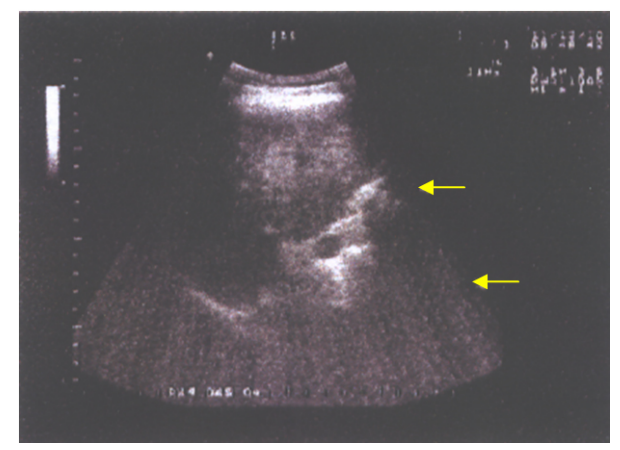

Figure 1. Transoesophageal echocardiography of the liver of the patient. It showed a large-area necrosis.

Table 1. Laboratory results of the 46-year-old man.

\begin{tabular}{ccccccccc}
\hline & \multicolumn{1}{c}{ Date } \\
& $\begin{array}{c}29 \\
\text { December }\end{array}$ & $\begin{array}{c}\text { December } \\
\text { 2005 }\end{array}$ & $\begin{array}{c}\text { January } \\
\text { J }\end{array}$ & $\begin{array}{c}\text { January } \\
2005\end{array}$ & $\begin{array}{c}\text { January } \\
2006\end{array}$ & $\begin{array}{c}\text { January } \\
2006\end{array}$ & $\begin{array}{c}\text { January } \\
2006\end{array}$ & $\begin{array}{c}\text { February } \\
2006\end{array}$ \\
\hline TBiL $(\mu \mathrm{mol} / \mathrm{L})$ & 95.8 & 142.5 & 262.1 & 329.2 & 431.2 & 526.5 & 31.68 & 20.83 \\
TP (g/L) & 75.3 & 70.5 & 68.7 & 66.6 & 68.9 & 69.8 & 61 & 57.1 \\
ALB (g/L) & 40 & 37.9 & 35.6 & 33.6 & 33.5 & 33.4 & 30 & 34.79 \\
ALT (U/L) & 894 & 853 & 809 & 320 & 256.8 & 68 & 50.59 & 35.4 \\
AST (U/L) & 1300 & 893 & 864 & 245 & 196 & 131 & 129.7 & 88 \\
GGT (U/L) & 221 & 199 & 140 & 113 & 93 & 63 & 46 & 43 \\
CHE (U/L) & 4653 & 4487 & 2809 & 1792 & 1980 & 2400 & 2808 & 3611 \\
\hline
\end{tabular}


Since the patient experienced the attack, we carried out the examination of HEV RNA in blood serum and excrement, and found that the HEV RNA appeared to be positive reaction. Subsequently, we sequenced the partial HEV gene, and analysised it by alignment and phylogenetic analysis. It showed that the HEV in blood serum and excrement of the patient belonged to the genotype IV. The homology with JYI-ChiSai01C, which is a HEV genotype IV strain, was 92.5\%. The homology with the other genotype IV strains was above 85\% (Figure 2 and Figure 3).

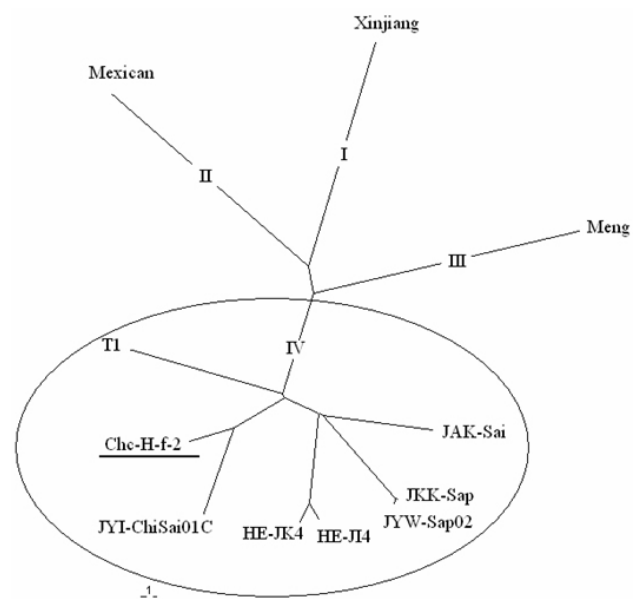

Figure 2. A phylogenetic tree of the HEV isolated from the patient based on nt 5997 to 6344 of the ORF2 gene region. The tree was constructed, and analysed by the Phylip software. The HEV isolated from the patient belong to the genotype IV. GenBank accession numbers with corresponding codes used in the text are as follows: Xinjiang (D11092), Mexican (M74506), Meng (AF082843), AB080575 (HE-JI4), swJ13-1 (AB097811), HE-JA1 (AB097812), JSN-Sap-FH (AB091395), HE-JK4 (AB099347), JAK-Sai (AB074915), JKK-Sap (AB074917), JYW-Sap02 (AB161719), JYI-ChiSai01C (AB197674), T1 (AJ272108), swCH25 (AY594119).
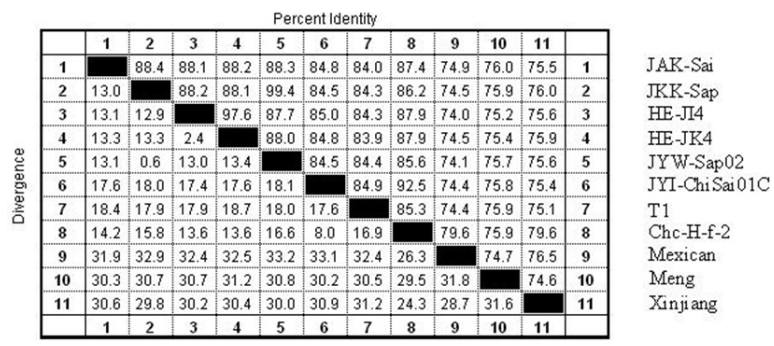

Figure 3. Nucleotide homology analysis between the HEV isolated from the patient and the other HEV. The nucleotide homology analysed by Clustal W. The homology with JYI-ChiSai01C, which is a HEV genotype IV strain, was $92.5 \%$. The homology with the other genotype IV strains was above $85.0 \%$. The homology with the other genotype was below $80.0 \%$.

Table 2. Blood clotting system test.

\begin{tabular}{ccccccc}
\hline \multicolumn{7}{c}{ Date } \\
& $\begin{array}{c}31 \\
\text { December } \\
2005\end{array}$ & $\begin{array}{c}4 \\
\text { January } \\
2006\end{array}$ & $\begin{array}{c}\text { January } \\
2006\end{array}$ & $\begin{array}{c}\text { 12 January } \\
2006\end{array}$ & $\begin{array}{c}\text { 23 January } \\
2006\end{array}$ & $\begin{array}{c}\text { January } \\
2006\end{array}$ \\
\hline PT (sec) & 18.7 & 22.5 & 24.5 & 26.3 & 28.5 & 38.8 \\
PTR (\%) & 52.6 & 37.7 & 32.3 & 30.8 & 24.6 & 17.8 \\
INR & 1.52 & 1.83 & 1.99 & 2.06 & 2.72 & 7.11 \\
APTT (sec) & 39.3 & 58.2 & 73.8 & 73.5 & 74.8 & 72.1 \\
TT (sec) & 21.3 & 25.3 & 29.8 & 28.4 & 27.5 & 29.4 \\
FIB (g/L) & 1.01 & 2.5 & 2.18 & 2.03 & 1.98 & $<1.4$ \\
\hline
\end{tabular}


After the patient was hospitalized, we took the anti-viral, decreasing ferment and jaundice measures. However, there was no significant improvement, so the patient was transferred to another hospital and received continuous treatment there with still no improvement. The patient died on the 11th day after he was transferred.

\section{Discussion}

Mixed infection with hepatitis E virus (HEV) occurred in patients with chronic hepatitis B virus (HBV) infection is frequent [1]-[18]. It often leads to patients has a protracted course with high morbidity and mortality [3].

Nowadays, Intensive investigation has revealed that HEV mixed infection inhibits HBV replication [1] [4]-[6]. At the same time, some researchers think that HEV infection may activate the replication of HBV [8]. However these finding mainly based on the epidemiology.

As we reported, the patient's HBV DNA was $<10^{3}$ copies/ml before he was infected by HEV, but after the infection, his HBV DNA reached $8.51 \times 10^{5}$ copies/ml along with other biochemical higher quota. It suggested that the patient died as a result of the HBV in his body being activated after he acquired HEV, which caused the large-area necrosis in his liver. This case revealed that HEV mixed infection may activate the replication of HBV, not inhibits HBV replication. However, the questions are required to be further studied, such as how HEV activates HBV, and what the vital mechanism is between the superinfection of HEV and HBV.

\section{Acknowledgements}

This work was supported in part by a research grant from The National Basic Research Program (Grant no. 2005CB523005).

\section{References}

[1] Cheng, S.-H., Mai, L., Zhu, F.-Q., Pan, X.-F., Sun, H.-X., Cao, H., Shu, X., Ke, W.-M., Li, G. and Xu, Q.-H. (2013) Influence of Chronic HBV Infection on Superimposed Acute Hepatitis E. World Journal of Gastroenterology, 19, 5904-5909. http://dx.doi.org/10.3748/wjg.v19.i35.5904

[2] Zhao, J., Wang, S., Zhang, T., Liu, P., Zhou, G.D., Sun, Y.L. and Yin, T.Y. (2001) Pathological and Virological Studies of the Liver Tissues from the Patients with Sporadic Hepatitis E. Chinese Journal of Experimental and Clinical Virology, 15, 205-207.

[3] Monga, R., Garg, S., Tyagi, P. and Kumar, N. (2004) Superimposed Acute Hepatitis E Infection in Patients with Chronic Liver Disease. Indian Journal of Gastroenterology, 23, 50-52.

[4] Guan, Q.-F., Zhang, Y.-X. and Sun, H.-R. (2000) Clinical Analysis and Effect on Replication of HBV in Chronic Hepatitis B with HEV Superinfection. Journal of Xinjiang Medical University, 23, 234-235.

[5] Zhang, Y., Liu, Y.L., Sun, J.Y. and Tian, G.S. (2005) Differences and Similarities between Superinfection of Hepatitis A and E in Chronic Hepatitis B. Clinical Medicine of China, 21, 1088-1090.

[6] He, S., Long, Y., Pang, C. and Hu, N. (1998) Analysis of Results of Serum HBV Markers in Patients with HBV and HEV Super Infect ion. Journal of Guangdong Medical College, 16, 34-38.

[7] Shao, F.Z. (1997) A Study on the Epidemiology and Clinical Characteristics of Hepatitis E in Tianjin Area. Chinese Journal of Epidemiology, 18, 267-269.

[8] Zhang, X.F., Yan, M.H. and Mao, W.Z. (2001) Clinical Study on Superinfection of Hepatitis B and E. Acta Academiae Medicinae Jiangxi, 41, 102-103.

[9] Kumar, A., Aggarwal, R., Naik, S.R., Saraswat, V., Ghoshal, U.C. and Naik, S. (2004) Hepatitis E Virus Is Responsible for Decompensation of Chronic Liver Disease in an Endemic Region. Indian Journal of Gastroenterology, 23, 4546.

[10] Ramachandran, J., Eapen, C.E., Kang, G., Abraham, P., Hubert, D.D., Kurian, G., Hephzibah, J., Mukhopadhya, A. and Chandy, G.M. (2004) Hepatitis E Superinfection Produces Severe Decompensation in Patients with Chronic Liver Disease. Journal of Gastroenterology and Hepatology, 19, 134-138. http://dx.doi.org/10.1111/j.1440-1746.2004.03188.x

[11] Hamid, S.S., Atiq, M., Shehzad, F., Yasmeen, A., Nissa, T., Salam, A., Siddiqui, A. and Jafri, W. (2002) Hepatitis E Virus Superinfection in Patients with Chronic Liver Disease. Hepatology, 36, 474-478. http://dx.doi.org/10.1053/jhep.2002.34856

[12] Chu, C.M., Yeh, C.T. and Liaw, Y.F. (1999) Viral Superinfection in Previously Unrecognized Chronic Carriers of Hepatitis B Virus with Superimposed Acute Fulminant versus Nonfulminant Hepatitis. Journal of Clinical Microbiology, 
37, 235-237.

[13] Coursaget, P., Buisson, Y., N’Gawara, M.N., Van Cuyck-Gandre, H. and Roue, R. (1998) Role of Hepatitis E Virus in Sporadic Cases of Acute and Fulminant Hepatitis in an Endemic Area (Chad). American Journal of Tropical Medicine and Hygiene, 58, 330-334.

[14] Chow, W.C., Lee, A.S., Lim, G.K., Cheong, W.K., Chong, R., Tan, C.K., Yap, C.K., Oon, C.J. and Ng, H.S. (1997) Acute Viral Hepatitis E: Clinical and Serologic Studies in Singapore. Journal of Clinical Gastroenterology, 24, 235238. http://dx.doi.org/10.1097/00004836-199706000-00011

[15] Tan, D., Im, S.W., Yao, J.L. and Ng, M.H. (1995) Acute Sporadic Hepatitis E Virus Infection in Southern China. Journal of Hepatology, 23, 239-2345. http://dx.doi.org/10.1016/S0168-8278(95)80001-8

[16] Tsai, J.F., Jeng, J.E., Chang, W.Y., Lin, Z.Y. and Tsai, J.H. (1994) Antibodies to Hepatitis E Virus among Chinese Patients with Acute Hepatitis in Taiwan. Journal of Medical Virology, 43, 341-344. http://dx.doi.org/10.1002/jmv.1890430405 